\title{
Ethnologies
}

\section{The Fiddle Burning Priest of Mabou}

\section{Jodi McDavid}

Volume 30, numéro 2, 2008

Hommage à Peter Narváez

In Honour of Peter Narváez

URI : https://id.erudit.org/iderudit/019948ar

DOI : https://doi.org/10.7202/019948ar

Aller au sommaire du numéro

Éditeur(s)

Association Canadienne d'Ethnologie et de Folklore

ISSN

1481-5974 (imprimé)

1708-0401 (numérique)

Découvrir la revue

Citer cet article

McDavid, J. (2008). The Fiddle Burning Priest of Mabou. Ethnologies, 30(2),

115-136. https://doi.org/10.7202/019948ar

\section{Résumé de l'article}

Le père Kenneth MacDonald a été le curé de Mabou, à l'île du Cap-Breton, de 1865 à 1894. Les documents écrits le dépeignent comme un censeur social pratiquant une discipline très stricte : condamnant la consommation d'alcool, réprouvant les pique-niques et dictant à ses paroissiens pour qui il fallait voter. Toutefois, les écrits semblent passer sous silence l'événement dont les

habitants parlent encore : comment il est allé de porte en porte pour brûler leurs violons. Bien qu'elle ne soit qu'une petite ville rurale, Mabou revêt une grande importance culturelle au Cap-Breton, en étant même considérée comme le berceau de la musique traditionnelle du Cap-Breton. C'est en effet le violon qui est l'icône centrale des manifestations à la fois traditionnelles et populaires de cette musique.
Ce document est protégé par la loi sur le droit d'auteur. L'utilisation des services d'Érudit (y compris la reproduction) est assujettie à sa politique d'utilisation que vous pouvez consulter en ligne.

https://apropos.erudit.org/fr/usagers/politique-dutilisation/ 


\section{The fiddle Burning Priest of Mabou}

Jodi McDavid

M emorial U niversity

W hen I was growing up, the most important people in the community were the fiddler and the priest (John Allan Cameron).

W hen I first moved to Cape Breton, time and again I was presented with one kernel narrative (Kalèik 1975): "We had a priest here that burned our fiddles." It became clear to me that locals wanted to tell the story of this priest, had told it before, and had told it so often that, for them, it needed little contextualizing. The priest as a positive figure is amply attested to in both the lore and the written record, but the negative priest - one who does not conform to community expectations, and who may be the exception rather than the rule - seems to be relegated to the lore alone. This article $e^{1}$ explores one such story through the framework of legend.

1. It is my great pleasure to contribute to this festschrift for Peter $\mathrm{N}$ arváez. I think of Peter fondly as a very dynamic and intelligent friend and teacher. I took a number of courses from him during my years as a graduate student - he exposed me to some areas of folklore scholarship that certainly did not come easy to me, but he was always very encouraging and patient as I struggled to catch on! 0 utside of class he was always willing to contribute his talents when called upon and his time when requested. In the years since he was my teacher we have crossed paths at several conferences and had many meaningful conversations about academic life, thesis writing, and so on. It was in Peter's nature to take the time to discuss these issues with me, but their importance at those career "crossroads" cannot be overestimated. 
$\mathrm{H}$ istorically, the priest has had an impact in small $\mathrm{A}$ tlantic $\mathrm{C}$ anadian communities, as elsewhere, in the interpenetrating spheres of politics, community economics, religion, and culture. Coping mechanisms to deal with the seeming omnipotence of the priest include expressions of ambivalence, anger, and amusement. These expressions are typically manifested in legend, song, jokes, dites, memorates, proverbs, personal experience narratives, and so on. In my work, ${ }^{2}$ I choose to focus primarily on the identifiable named priest: priests who primarily appear in gossip or historical legends. W hile I use motifs and variations from more general legends and folkloric forms, my primary interests lie with those expressions which detail the role and actions of one priest within a specific community, in this case, in Mabou, Cape Breton Island, Nova Scotia.

Following the presentation of the legend reports, I place them within four overlapping contexts: the history of Cape Breton; other accounts of the life of the legend's central figure, the priest; the significance of the fiddle in Cape Breton culture; and the character of the priest in both local history and local and international folklore.

\section{The Legend}

The following seven legend reports are about Father Kenneth $M$ acD onald, first Pastor at $M$ abou, C ape Breton, from 1865-1894. They are representative examples, appearing in the oral and written tradition, in academic articles, vernacular publications, student papers, revival folksongs and educational videos.

2. This article emerges from work conducted for my PhD thesis on the role of the priest as illustrated in the folklore of A tlantic C anada. I have been looking at personal experience narratives, archival holdings, and popular vernacular fiction in order to collect a variety of samples in a variety of communicative genres. My work uses folkloristic approaches, fieldwork and reinterpretations of previous folklore collections to explore the idea that priests have power, social control, and control over the sacraments, and that this power isheightened in small community contexts. This research was funded in part by a PhD SSH RC grant. Earlier versions of this paper were presented at the International Society for C ontemporary Legend R esearch, Logan, U tah, M ay 2007, and at the A nnual meeting of FSA C/A CEF, Sydney, N S, M ay 2008. I am thankful to Bill Ellis and Diane $\mathrm{G}$ oldstein for their valuable comments, to my advisor Diane Tye, and to my partner Ian Brodie. 
Version A. Academic article: Kenneth Nilsen, "The Role of the Priest in the Gaelic Folklore of Nova Scotia."

Like Fr Kenneth, Fr A ndrew seized all the violins belonging to his parishioners, but unlike Fr Kenneth he did not break them into pieces - he just kept them and as a result had a house full of violins. We may note here that Fr A ndrew played the violin himself. Like Fr Kenneth, he was against dances because of the drinking and courting that followed (1996-1997: 185-186).

Version B. Student paper: Tristan Mac Lean, "Staying Alive: Report on Cape Breton Concertsand Festivals."

The first attack on the Cape Breton musical culture was by the church, specifically, Reverend Kenneth J. M acDonald a parish priest of Mabou from 1865-1894. The church at the time held that the fiddle, which is the base instrument of the Cape Breton culture, and dancing, were tools of evil. The result was an attempt to banish them. Later on the churches views changed to tolerance, then acceptance, and finally endorsement. A cynic might conclude that this has to do with the financial benefits reaped from parish picnics ([n.d.]: 4).

Version C. Master's thesis: lan Franc is MacKnnon, "Fiddling to Fortune."

A s was the case in Presbyterian Scottish communities on occasion, these fire and brimstone clergymen attempted to stamp out the music and all the perceived debauchery that accompanied it. The best known case of this in Cape Breton occurred during the pastorship of Father Kenneth MacDonald who was parish priest of the Mabou-W est Lake A inslie parish from 1865 to 1894. In an attempt to quell the demoniacal atmosphere which he felt centered around the music in his parish, he had all the pipes and fiddles gathered up and burned (1989: 25).

Version D. Academic article: Marie Thompson, "The Myth of the Vanishing Cape Breton Fiddler."

In the late nineteenth century, Father Kenneth MacDonald, a $\mathrm{C}$ atholic priest in $\mathrm{M}$ abou, attempted to discourage fiddling because he thought it led to excessive alcohol consumption. A few fiddlers handed over their instruments to him to be tossed in the fire ( $\mathrm{M}$. Thompson 2006: 8). 
Version E. Oral tradition: Father Angus Momis.

A $n$ old parish priest, he did confiscate the fiddles. A nd ah, in many cases I don't blame him. But the people were pretty smart ... they had two fiddles and they always gave him the worst fiddle [chuckles] (Highland Legacy 2006).

Version F. CD liner notes: Willie Kennedy, Cape Breton Violin.

Way back before I was born there was the old priest, smashing or burning all the fiddles in M abou. There were musicians back then who'd give him a poor fiddle to smash and keep a better one hidden. Eventually the Cape Bretoners got wiser and stood up for themselves. But what's the harm in violin music, you know? I've hear some say, "I don't want to go to heaven unless there's music there" and I guess I about agree with that, eh? (2002: para. 34).

Version G. Folk revival song: Gopher Baroque, "Bum Ye Fiddles Bum." (Lyrics taken from http://www.gopherbaroque.com/ Reproduced with permission.)

Father M cK innon had a dream, he heard a 1000 violins.

They sounded so obscene, calling souls to sin.

The condemned began to dance forgot to weep and gnash their teeth.

Their joyous trance scandalized the priest.

Chorus:

Burn ye fiddles burn, burn ye fiddles burn. ( $\mathrm{x} 2$ )

Father M CK innon's' looking for kindling,

Burn ye fiddles!

$\mathrm{N}$ ext Sunday at the mass he gave a solemn homily, $\mathrm{H}$ e said the devil craved to hear that fiddle de diddle de dee.

To play the violin, he said was vile and coarse.

Scraping the guts of a cat with hair from the rear of a horse. $\mathrm{H}$ e searched the parish wide from cell loft and spire.

In the field behind the manse he built a ten foot fiddle pyre; and when the pyre was lit the amattis' (sic) flared up well but the strads they hissed and spit, like unrepentant souls from hell! But as the fiddles flamed there came an impish wind, that filled to (sic) poor priests' lungs with essence de violin. The parish has been purged of tapping toe and heel, entirely exorcised of strathspey, jig and reel.

The priest who breathed in deadly fiddle smoke has etched upon his sleepless brain all those dreaded fiddle notes (Grant 2006). 
Before attempting any sort of analysis, I will look at the context from which the narratives emerge and examine some biographical elements of this priest's life for further hints on why these legends are commonplace today.

\section{Context: Cape Breton Local History ${ }^{3}$}

$\mathrm{C}$ ape Breton Island is part of the province of $\mathrm{N}$ ova Scotia: its history is complex, and the conditions surrounding its re-annexation with the mainland were unusual and are still publicly contested by a small, but vocal, minority. Generally, it can be said that a tension does still exist between Cape Breton Island and mainland N ova Scotia. Regionalism and nationalism are al ive and well in this area and are often accompanied by a sense of pride: there are many public indications such as signs which encourage residents to "Think Cape Breton First" for purchases instead of making the trip to the shopping centres in $\mathrm{H}$ alifax. The Island was physically linked to mainland Nova Scotia by the construction of the Canso Causeway in 1955, but prior to that it enjoyed greater geographical autonomy. Despite its uniqueness and identification as a region within N ova Scotia, political judgements such as the Diocesan seat's location on the mainland, in A ntigonish, continue to be points of contention. Statistics $\mathrm{C}$ anada data indicate that $\mathrm{C}$ atholics outnumber Protestants two to one in Cape Breton, while Protestants outnumber Catholics on the mainland by the same proportion.

Marie Thompson provides a good synopsis of $C$ ape Breton settlement:

Cape Breton culture traces its origins to the Scottish Highland immigrants who began arriving in Nova Scotia in the late 1700 s. A fter their defeat by the British at Culloden in 1745, clan chieftains lost their military power. M any became landlords and ordered villages to be cleared to facilitate livestock farming. Some of those evicted moved to crofting tenancies and worked in the kelp-gathering industry

3. Cape Breton history is a far more complex topic than what I present here, one which should include moments like the expulsion of the A cadians, the movement of the Loyalists into the area following the A merican Revolutionary $W$ ar, and so on. This brief history is only supplied to set up the context of this paper and is therefore purposely sparsely detailed. See Feintuch 2004 for a more detailed account of the context of $\mathrm{C}$ ape Breton fiddling. 
in order to pay their high rents. Before 1815 many left of their own accord to go to North A merica. A fter 1815 the kelp industries collapsed and more lands were cleared of people to make way for sheep. Thus began a major migration of highlanders, both Roman $\mathrm{C}$ atholic and Protestant, westward across the $\mathrm{A}$ tlantic to $\mathrm{N}$ orth $\mathrm{A}$ merica and beyond. The highlanders who left old Scotland to seek freedom of expression and opportunity in a N ew Scotland brought their bagpipes, fiddles and dance steps with them. M ean while, both political and religious persecution of $\mathrm{H}$ ighland customs led to a discontinuance of many styles of music and dance in Scotland (M. Thompson 2006: 7-8).

U pon immigration to Cape Breton, many Scots worked in the coal mines in poor and dangerous conditions at subsistence wages. The Scots people underwent challenges in establishing ownership of land, having access to $\mathrm{G}$ aelic-speaking priests, and getting adequate pay for work. Like most of A tlantic C anada, small coastal towns sprung up in Cape B reton based on fishing, farming, or access to natural resources. $\mathrm{M}$ abou, located in Inverness County, Cape Breton is one such town, a coastal agrarian community which was also proximate to coalfields. Founded in 1797, the area is predominately Catholic, with a current population of approximately 1000 . This is a decline since the late $1880 \mathrm{~s}$, when estimates state it as 1190, comprising 250 families ("H istory" [n.d.]: para. 17).

A Ithough a small rural town, $\mathrm{M}$ abou has risen to one of cultural importance in Cape Breton. It is considered the heart of $C$ ape Breton traditional music, which, especially since the decline of industry on the east of the Island, has become increasingly commodified and intrinsically linked with tourism. Of central iconic importance in both the folk and popular manifestations of this music is the fiddle. M abou is constructed in tourist literature, and to an extent by its residents as well, as a pastoral utopia, providing the perfect example of rural Scots-Gaelic Cape Breton, and a sharp contrast to industrial Cape Breton. Historically, this area is the birthplace and the stomping ground of many a "fine fiddler."

\section{Father Kenneth as Historical Figure}

Kenneth Joseph MacDonald was born in South River, A ntigonish County, N ova Scotia on May $10,1821 .{ }^{4} \mathrm{He}$ was educated at nearby

4. Information on Fr Kenneth's life is taken from Rankin (1945) and Johnston (1971). It should be noted there are some discrepancies between the two. 
St. A ndrew's Grammar School, and went on to St. Francis Xavier College in A richat in 1853 at the age of 32. He spent the following two years (1854-1856) at the $G$ rand Seminary of Q uebec, and was ordained in December of 1856. A ccounts suggest that this swift training was due to a "scarcity of priests" (Rankin 1945: 5). H is first post was as A ssistant at $A$ richat from January to $M$ ay of 1857 , after which he became the first Pastor at Ingonish and Bay St. Lawrence until September of that year. For two years he fulfilled the position of Pastor at West River/St. Joseph's (September 1857 to July 1859), followed by a six-year appointment to A risaig and Bailey's Brook (July 1859-June 1865).

$\mathrm{M}$ acDonald became the first Pastor of Port Hood and Mabou in 1865 , and he remained in this area until his retirement in 1894. The reach of his parish changed over time. $\mathrm{He}$ always retained $\mathrm{M}$ abou, but Port Hood dropped from his responsibilities in 1868, while West Lake A inslie was added in 1871. During his tenure at $M$ abou he built the glebe house and in 1887 brought the Congregation of N otre Dame nuns, and he made preparations for a new church. He retired in 1894 at age 72 because he "was crippled" from a fall (Rankin 1945: 5). He spent some time in the area but his health required him to move first to St. Francis Xavier in 1900, and then to the town of Reserve M ines the following year. He became a resident of St. Joseph's H ospital in Glace Bay in 1902 where he remained until his death in 1910. He is buried in Sacred H eart Cemetery in Sydney.

A search of the archives and holdings of the Beaton Institute - the cultural and historical archives of C ape Breton Island - and a perusal of local vernacular histories reveal few sources of information, although Fr Kenneth is mentioned in church histories and early accounts of the region. Most noteworthy is the article written by Fr Duncan J. Rankin, who as a young man knew Fr Kenneth both as his priest and as a friend and teacher of his mother, who took a year of schooling from him in preparation for obtaining her teaching license. The eight pages he wrote about Fr Kenneth comprise the best account of his life that I have had access to, and one of the first vernacular histories which include him, much less make him the focus of the discussion. W ritten in 1945, the piece reads in part as though it was written by a hagiographer, an apologist, and a friend. ${ }^{5}$ For example:

5. Biographical works about priests in this diocese were not uncommon, and although their format and style has changed somewhat, this body of work continues. See for example, Stewart Donovan's recent book (2007) about a Cape Breton priest, T he Forgotten W orld of R.J. M acSween: A Life. 
He was so fearless in denouncing evil that badly-disposed people gave him considerable trouble and tried - as hard as their unscrupulous conscience permitted them - to undermine if not to destroy his influence (Rankin 1945: 5).

In order to more fully explore the written record, which supports and gives credence to the legends which surround him, I have quoted extensively from Rankin's work. In discussing the stories told in the home, Rankin makes reference to bible stories, but also says:

Good dancers, singers, musicians and those who could fight well at weddings were al so spoken about, and stories of the priests who labored so zealously in the parishes of M abou, Broad Cove, Port Hood, Cheticamp and Judique also formed a part of our fireside chats. Since my mother had spent the year preparatory to obtaining a teacher's license going to school from Father Kenneth's, she was particularly [fond] of talking about this zealous priest (Rankin 1945: 3).

This narrativisation of the priest's actions and the discussion of his heroic deeds give us some sense of the importance that oral stories about specific individuals played at this time. A s well, it should be noted that R ankin put the priest in one category, and the "G ood dancers, singers, musicians and those who could fight well at weddings" in another by his use of the word "also," suggesting an opposition. This paragraph essentially forms the introduction to Rankin's account.

Rankin seems to suggest that $\mathrm{Fr}$ Kenneth was not adequately supported by the Bishop. He notes that "one regrets that, in his old age, he could not have been given the help that would enable him to continue the work he had done with such great zeal" (Rankin 1945: 6). It becomes clear throughout the text that Rankin feels that Fr Kenneth is one of the unsung heroes of the early priesthood in Cape Breton. That being said, Rankin is painfully aware of the issues that many other community members had with the priest and gives several examples which highlight the extent of his influence over the parishioners:

We are told that much of the farm work such as plowing, sowing, moving, harvesting, cutting and hauling the fuel for the church and glebe, was done by those who were in arrears with their dues. In so far as contributing to the support of the pastor, the church, and the school, was concerned, Father Kenneth insisted that the law of the church be carried out (Rankin 1945: 4).

In a small community with economic disadvantages, there were likely many who were in arrears with their dues, and farmwork and 
churchwork undoubtedly became a public performance and expression of lack of ability to pay cash.

Those who remember the years between 1890 and 1898 know that as a general rule - the priests of the A ntigonish Diocese voted on the conservative ticket, and many of them visited their parishioners at election time in order to influence them to vote for that party. Father Kenneth was one of this number. M any of the laity who honestly believed that, as $\mathrm{C}$ atholics, they were supposed to cast their vote as they thought proper and that not even a priest had any right to influence them in this connection regretted that their pastor, whom they admired and respected, thus interfered in politics (Rankin 1945: 7-8).

A s Rankin discusses, the church at this time had no formal stance regarding influencing voting, and there were no regulations either proscribing or requiring preaching party politics from the pulpit. The locals understood that it was within their rights to vote as they saw fit.

It is a well known fact that - later on - Father M acD onald, like many another priest, fully realized that if he had followed the above rule [not influencing votes] his relations with the people would have been much more amicable, both pastor and parishioners would have been happier, and the memory of these years would have been much more pleasant (Rankin 1945: 8).

Rankin alludes to problems in the parish, but one must read between the lines; the implication of "memory of these years" here suggests, once again, a narrativization of his behaviour among the parishioners.

However, from his placement in M abou in 1865 to the present day (well over a century after his retirement), Fr Kenneth is best known for his objection to drinking and to picnics, made manifest when he collected and burned fiddles.

Father Kenneth $M$ acD onald was one of the most earnest workers of his time in the cause of temperance. So bitterly did he regret the harm done by drinking that nothing short of total abstinence, could be regarded by him as a proper attitude towards drink. Because he found that dances, picnics and such outings lent themselves to drinking he strenuously opposed them, and those whom he found indulging in intoxicating liquors had to pay the penalty (Rankin 1945: 8).

Fr Kenneth's distaste for picnics crippled the potential financial resources of the church. A lthough the fiddle-burning legend often becomes framed as a narrative about his distaste for the music, the core of his rejection of picnics and other festivities seems to be that he felt 
they led to drinking. A t first glance, it may not be clear that the decision to prohibit this sort of gathering would have an economic outcome, but it undoubtedly did. Even his eulogizer disagrees with him on this point:

The last time I saw him before his death he again insisted that picnics were not the proper channels through which to raise money for any charitable purpose - least of all for building a church or convent. He was sorely disappointed because, just then, I was going to have a picnic in order to make funds to build a glebe house (Rankin 1945: 8).

Despite Fr Kenneth's rejection of picnics, he was a successful fundraiser.

Let it be said to his (own) credit as a financier that, at Mabou, he built, a carriage house, barn, glebe-house, convent and he had $\$ 9,000.00$ laid by to build a church - a good standing surely - and especially in those early days when there was less money in circulation (Rankin 1945: 8).

A s well, the spiritual caretaking of the parish was not in question.

W hether or not the strict discipline exercised by this earnest apostle was responsible for the prosperity and good standing of the parish we may not and can not judge, but certain it is that, during his pastorship, exceptional progress was made and, "[t]he parish was giving a larger percentage of priests to the Sacred M inistry and more subjects to the religious life than were any of the neighbouring parishes" (Rankin 1945: 8).

A fter a thorough accounting of MacDonald's life, Rankin moves his pamphlet towards a close, but before concluding on how the priest's work lives on, he gives anecdotes from a man who was the young nephew of Reverend John MacN eil, the priest's friend from college and the seminary.

[The] old priest came into the hall-way and was taking off his coat when the young boy, very politely, offered to put it on the peg. H owever, the priest declined the offer, and told him he did not know how to hang the coat.... A t the time of this incident the boy decided that the priest was very fussy (Rankin 1945: 9).

Clearly Fr Kenneth was a difficult and challenging man. A nd despite its upbeat tone, Rankin's work is quite critical:

It has been said by one of Father Kenneth's parishioners that oftentimes he seemed not to be able to distinguish between the crime and the 
person who committed it - between the sin and the sinner (Rankin 1945: 7).

In sum, Rankin and others describe Fr Kenneth as a strict disciplinarian and social advocate: he was against the consumption of alcohol; he disliked picnics; he would withhold an individual's religious services until accounts were paid to him in full; and he told his parishioners how to vote.

W hy, then has the legend about Fr Kenneth burning fiddles persevered? ${ }^{6}$ A cross the legends I collected, actions are fairly consistent.

1. Fr Kenneth either confiscates, burns, hoards, banishes, or breaks fiddles.

2. Fiddlers give them up, hide them, trick him, or are absent from the narrative.

A nd a coda often appears:

3. The tradition lives on; several fiddlers are living proof of his failures.

Furthermore, the legend fits in with two local ideologies:

a) Some priests are inherently flawed and/or abuse their authority

b) The musical tradition in Cape Breton can survive, and has survived, despite all odds.

I suggest that because the legend involves fiddlers from $M$ abou, and because the Mabou fiddling tradition is still very strong today, this legend has become part of the occupational folklore of Cape Breton fiddlers. The widespread attestation in folklore of the flawed priest, as discussed below, provides support for the first ideology and aids in the transmission of the legend. But this second ideology requires some further contextualisation.

6. Version $\mathrm{G}$ is a folksong, written by the $\mathrm{O}$ ntario group $\mathrm{G}$ opher Baroque. A Ithough they reference a "Father MacKinnon," in an e-mail exchange with a group member I was told explicitly that it is based on the same story (with some liberties added, based on the reported incident of Ontario Provincial Police trying to burn marijuana stores and having a slight surprise when the wind changed direction). The legend, then, as performed and reconfigured by this group, has extended to at least a national audience. 


\section{The Fiddle's Cultural Resonance}

A s much as the priest predominates in all these narratives, so does the fiddle. In fact, one may wonder if this is a legend about a priest or actually a legend about fiddlers, or both. Undoubtedly, there is the temptation and potential to draw connections between this narrative and supernatural ones about priests and fire, or the devil and fiddles. ${ }^{7}$ There has long been a connection between fiddlers and the devil, and fiddlers toy with these ideas, even today, with song titles such as A shley M aclsaac's "D evil in the Kitchen." But the legend of Fr Kenneth has no supernatural elements, and to look at it through that lens marginalises the cultural constructions that promote the legend telling. Perhaps more closely linked is the fact that the banning of bagpipes is common in the folklore of Scots people. The beliefs and practices of Scots Protestantism have contributed to this, but so too has a prevailing sense of a deliberate effort against Scottish nationalism. But in Cape Breton, these legends are only attributed to Fr Kenneth. I found one example which alludes to this belief crossing denominations:

\footnotetext{
The fiddle was supposed to be the instrument of the devil. A nd I believe that these clergy who were, who caused so much destruction of the fiddles, they destroyed, had many destroyed and in recent weeks I discovered that this had happened in both $\mathrm{C}$ atholic and Protestant areas (quoted in Highland Legacy 2006).
}

In $\mathrm{C}$ ape Breton, though, the fiddle is iconographic. ${ }^{8} \mathrm{H}$ ere, in Cape Breton, the fiddle stands for the "old country," for the "new country," for family, for tradition, for the working class, for hardship, for status (and lack thereof), and for counter-hegemonic power. The fiddle is key in the promotion and maintenance of traditional music and culture in general. It has been reclaimed as a status symbol, and has become an iconographic cultural shorthand for "pure" or "honest" living. Fiddle music has been used to socialize, to deal with frustration without words, and to expel energy through energetic fiddling and dance.

The fiddle appears as a symbol in a variety of places on the Island as well as in a variety of forms such as roadside signs for the Ceilidh

7. In Bluenose $\mathrm{G}$ hosts, $\mathrm{H}$ elen $\mathrm{C}$ reighton cites several local variations of legends about drinking and dancing and the appearance of the devil as a response to these behaviours (Creighton 1957: 91-117).

8. There are only a few mentions of Fr Kenneth collecting bagpipes as well, likely due in part to the fact that Fr Kenneth objected to activities surrounding fiddle playing which do not take place to the same extent around bagpipe playing. 
Trail, tourist shops, and generic stores, on the signage and promotional materials for musical establishments such as Strasthpey Place in Mabou and the Celtic Music Interpretative Centre down the road in Judique, in the media throughout its online presence, in promotional material from the Centre for Cape Breton Studies at C ape Breton U niversity, in the "Big Fiddle" at the Sydney M arine Terminal, a huge landmark that plays pre-recorded fiddle music, and at several local family restaurant chains, typically wrapped with a ribbon of Cape Breton tartan and located in a place of prominence. A cademic and popular DVDs and books also make use of the image of the fiddle, a number of which are published each year.

In 1972 the CBC produced and broadcast a film called The Vanishing $C$ ape Breton Fiddler. Marie Thompson has recently written a critical piece on this production. Essentially, the fiddle tradition could be said to be in a perennial crisis. But for our purposes, Thompson quotes a few of the interviews which illustrate the sense of what the music means. On the difference between local music and that in Scotland:

They left for oppression, you could say, and once they arrived in this country they got the spirit of freedom and that spirit of freedom is expressed in the music, which is not found in the music of Scotland. You have a kind of sadness or sorrowful feeling in the music as played by the violin players over there. There's more gaiety and more joy and more freedom in the music here ( Fr John A ngus Rankin in M. Thompson 2006: 12, emphasis added). [In the documentary, Father Rankin explained how he perceived that the music had changed in Cape Breton.]

On the fear of the loss of the tradition from the lack of young fiddlers:

I think a very big part of our lives were at stake.... It's something very deep in our soul, our music... . A nd with our fiddle especially, I think it can express every feeling of the human heart ( Fr. Eugene Morris, in $M$. Thompson 2006: 19, emphasis added).

Others, too, produce a similar sentiment. David M ahalik notes that:

The music lives here, as much a part of the community as any person or building. It will survive no matter what happens around it because it always has. Through religious opposition, mass migration and now, a new generation's interpretation, the music has grown stronger (Mahalik 1996: 104).

U nderlying these comments is a sense of pride that the music survives as well as an idea that it becomes stronger with every attempt to strike 
at its core. In this context, it seems that the legend of Fr Kenneth may make a deeper statement than a surface reading suggests.

The legends and memorates surrounding Fr Kenneth, then, also comprise an aetiological legend: an explanation for the perseverance, challenges and belief in Celtic music today.

\section{Other Notorious Cape Breton Priests}

In general, the priest as a character features prominently in legend, although for the most part, these narratives tend to be supernatural legends, historical legends or morality tales with a similar complex of motifs and themes. Stith Thompson notes that the priest can often be an incidental designation give to a player in a legend, often a character that is meant to be one that exhibits a certain morality (or lack thereof). But just as often, "many of the old fabliaux in which the actors may belong to any trade or profession, or none at all, have frequently been retold as happening to the priest..." (S. Thompson 1946: 212). The $M$ otif Index of Folk Literature identifies one hundred and twenty-five clerical narrative motifs found repeatedly in tradition ( $S$. Thompson 1955-1958). A mong the themes noted are several which portray priests as nurturing or heroic, but a much larger number focus on sexual, farcical, and vindictive characteristics. A s Lawrence Taylor notes, "priest stories, and the beliefs and behaviour associated with such clergy are ... collective representations on the nature of religious power" (Taylor 1990: 164). The narratives provide an outlet for concerns otherwise unexpressed in folk religious culture and thereby form a cultural critique of priestly privilege and behaviour. The expression of political resistance through folkloric forms provides a socially acceptable counterhegemonic critical commentary on social issues.

Priests historically have held powerful roles, especially in communities where they provided the services one would typically now associated with elected offices. They made recommendations for further education, created legal documents, and settled disputes.

The priests' influence extended far and wide in the community, and $\mathrm{Fr}$ Kenneth is not unique. For example, in $\mathrm{T}$ he Company Store: James Bryson M CLachlan and the Cape Breton C oal M iners 1900-1925, John Mellor illustrates the role various sectors played in the battles against unionization. It is also worthy to note here that in some areas, 
the churches were closely aligned with the mines, and items such as church and hospital dues (keeping in mind that several hospitals were church-run) were automatically deducted from paycheques.

Through their untiring sacrifice, miners were organized into a union to demand better working conditions, but for their efforts they were vilified by the press, persecuted by the federal and provincial governments, the judiciary and the courts, the more affluent segments of $C$ anadian society, and even the clergy. During the turbulent strikes of the 1920s, ministers of all denominations openly sided with influential coal and steel producers in Cape Breton at the expense of the starving, evicted miners, even to the extent of waving U nion Jacks from their lofty pulpits as they solemnly warned their flocks of the danger of Bolshevik infiltration by godless atheists posing as union leaders (M ellor 1984: xvii).

In his master's thesis, "M ilitary A id to the Civil Power: The Cape Breton C oal Strike of 1909-1910," Ian A lexander A ndrews presents several examples of the priests' involvement in political affairs. Some comments refer to priests in general, "C otton's W eekly accused the church of being 'the faithful upholder of capitalism' for seeming to support the Dominion Coal Company in the dispute" (A ndrews 1987: 56). But A ndrews notes that this was not limited to $C$ atholic priests as "both C atholic and Protestant clergymen would take sides and openly support one side or the other" (57). M ost pointedly, priests threaten ed companies, writing letters to their owners and suggesting that they be taken seriously "because I am a priest and have influence which I can use to the great detriment of your company" (59).

$\mathrm{H}$ istorically, though, the event in which a priest's precise role was unknown and yet is still unforgiven was one priest's part in allowing the militia to set up machine guns on church property as part of the intimidation of striking workers (and there is a history of fatalities in Cape Breton strikes).

The priest of the Immaculate Conception Roman Catholic Church, Father $\mathrm{C}$ harles $\mathrm{M}$ CD onald, claimed to be away at the time and innocent of authorizing the militia to use the church property. It was reported that only 15 out of 250 members showed up for mass in his church the next Sunday, and the situation became so serious that the bishop launched and inquiry into the actions by his clergy (A ndrews 1987: 55).

Priests' power and control in the political realm also extended to the fishery. In her master's thesis "The Influence of Interest G roups on 
the Settlement of the Trawlerman's Strike in Petit de G rat in 1970," $M$ arguerite $M$ artha Balawyder mentions the priest of Petit de Grat's role in the continuation of the fishing industry.

\begin{abstract}
Like every fishing village in Richmond C ounty, Petit de Grat is a tightly knit community, where every member of the community is known; where the family continues to be a strong unit of society; and where the Roman Catholic parish priest is still considered both a religious leader and secular advisor (Balawyder 1973: 2).
\end{abstract}

A s early as 1929 a co-operative fish processing plant was established in Petit de G rat. Initially successful, the plant fell into the hands of an inefficient management and was about to be closed. Painfully aware of the hardship such a closing would cause, the parish priest, Father A. Boudreau, decided in 1950 to invite Booth Fisheries C anadian Company to Petit de Grat (3).

\title{
The Fiddler, the Fiddle, and Fiddling
}

There is clearly a power dialectic going on in the legend of Fr Kenneth similar to vernacular expressions which challenge priests' power by juxtaposing a priest with the town drunk, a young boy, or a wise man. Typically, the challengers are the individuals in society that have little to lose by confronting the priest. In the Fr Kenneth legend, the fiddler, represented by the fiddle, is the dissenting voice. The priest and the fiddler would have historically enjoyed a similar degree of power; both travelled, officiated at events such as weddings, and had large spheres of influence. To quote Rankin again:

\footnotetext{
Good dancers, singers, musicians and those who could fight well at weddings were also spoken about, and stories of the priests who labored so zealously in the parishes of M abou, Broad Cove, Port Hood, Cheticamp and Judique also formed a part of our fireside chats (Rankin 1945: 3).
}

Rankin seems to illustrate two bodies of narratives: on the one hand, those of the "dancers, singers, musicians and those who could fight well at weddings" and on the other hand, and perhaps even counter to this, "stories of the priests who labored so zealously." O ne may wish to consider who the priests laboured against, if not the people in the former category. $M$ arie Thompson interviewed noviciate turned musical performer, John A llan Cameron: "when I was growing up, the most important people in the community were the fiddler and the priest" (M. Thompson 2003: 
23). Perhaps it is not coincidence that the current premier of $\mathrm{N}$ ova Scotia is a fiddler and a dancer from M abou.

If Fr Kenneth did confiscate the fiddles, was he in any way justified? Thompson quotes one informant:

[T here] was a barn there flat on the ground and the house was ready, too, it was old, and had an awful lean to it, but there was people living in it, there was clothes on the line. A nd N eil said to my father, "there must be a good fiddler live there, Dan" he said. Everything was falling down (quoted in M. Thompson 2003: 22).

A $n$ impoverished fiddler was thought to be a good fiddler, ${ }^{9}$ and in many cases the life of a musician brought little pay, but much access to alcohol, a perceived social ill, which can be said for musicians even today. Fr A ngus Morris stated in $\mathrm{H}$ ighland Legacy that "in many cases I don't blame him." Beyond the affect of their lives on the musician themselves, various communities would travel to see the performers, and courting and drinking took place.

In most cases, in the Cape Breton context, priests have had a positive impact and were viewed as community assets, even promoting and participating in fiddle music. But some abused their power, and, naturally, a discourse must spring up to counter the dominant power, especially when priests were in physical minority but dominated community life. How priests influenced their parishioners differed, no doubt, according to many variables. Fr Kenneth's main tool appears to be fear. Nilsen writes, "Strictest of all, by all accounts, was Fr Kenneth M acDonald, parish priest of Mabou" (1996-1997: 185). Citing his informant, Donald Cameron, N ilsen continues:

DC tells the story of one M abou man who was known to fear al most nothing. O ne day another man asked him, "A Dhòmhnaill, nach eil an t-eagal ort ro' sian?" [Donald aren't you afraid of anything?] To which D òmhnall replied, "T ha, tha an t-eagal orm ro' dà rud: M aighstir Coinneach agus an tàirneanach!" [Yes, I'm afraid of two things: Fr Kenneth and thunder!] (185).

Of course, one wonders how long one could run a parish on quiet sustained fear and what it takes to create, maintain, and nurture that fear.

9. Perlman (2002) makes a similar case for the character of the impoverished fiddler in the Prince Edward Island context. Thanks to an anonymous reader for suggesting this reference. 


\section{Antic leric alism or Counterc leric alism?}

Did Fr Kenneth actually burn fiddles? It is a question for which I have no answer at this point. During a recent phone conversation with a local priest he noted that, when he was initially posted, he inquired among the older people of the parish to determine the veracity of the tale. While inconclusive, the absence of satisfactory "proof" caused him to suggest that Fr Kenneth must have simply taken the fiddles and was unable to return them a later date because they had fallen apart in his basement, a slightly less romantic narrative, perhaps betraying the influence of the only passively destructive actions attributed to $\mathrm{Fr}$ A ndrew in version A. Like most tellers, he provided his own explanatory coda, one which repositions his predecessor, Father Kenneth $\mathrm{M}$ acD onald, as a good priest who did an ordinary, but not extra-ordinary, disservice to his community.

But, as is often the case in folklore, the facts behind the legend of $\mathrm{Fr}$ Kenneth M acDonald matter less than the story's truths. The community feels that their fiddles were burned, and these fiddles are more than simple objects but a connection to their traditions and their past. Today the legend may act as a means to discuss modern priests' interest in the promotion of Celtic music. A s M arie Thompson notes:

Indeed, many priests themselves were proficient musicians and dancers. By the mid-20th century local $C$ atholic priests encouraged fiddle music and dancing at summer picnics. A t Broad Cove, the local Catholic priest initiated the first Broad Cove Scottish Concert in 1956, an afternoon of $\mathrm{G}$ aelic singing, fiddling, bagpiping, step dancing and $\mathrm{Highland}$ dancing on the first Sunday in A ugust ( $\mathrm{M}$. Thompson 2006: 8).

But it also may be a means to critique that involvement. For example, it can give way to this discussion of Fr Kenneth himself:

$\mathrm{H}$ e was not inconsistent but it is remarkable that, on the one hand Fr. $\mathrm{M}$ acD onald attacked fiddle playing and the ceilidh because they were associated with stills but presided over mass that used local violins in church (Gibson 1998: 203).

$O$ thers such as $\mathrm{G}$ lenn $\mathrm{G}$ raham note that, "T he $\mathrm{C}$ atholic clergy were early to recognize the important role of music and dancing in maintaining morale in a depressed economy" (G raham 2006: 57).

A Ithough priests in the area have incorporated fiddle music into worship, critics question these priests and suspect it is for the financial 
aspects, while locals are particularly mindful that newcomers learn "the history" and "the music."

In closing, one may be tempted to interpret these narratives and the beliefs they reflect as anticlerical. ${ }^{10} \mathrm{H}$ owever, rather than anticlerical, I propose that these narratives are counterclerical in that they suggest a reality counter to the dominant one and are essentially a body of counterhegemonic narratives that exist specifically about priests. They operate just as $\mathrm{N}$ arváez has argued that the N ewfoundland house wake does: "In clear opposition to the hegemony of official religion" (N arváez 2003: 114). In Mabou in particular, and in Cape Breton Island more generally, where both Catholicism and traditional music thrive, the story of a priest who burned fiddles is one expression of tension not only between clergy and parishioners, but between official and vernacular culture.

10. A nticlericalism is a catch-all term used inconsistently by historians and anthropologists, a theoretical framework, hermeneutic, or ideology rather than a theory. The term itself implies a value judgement, something that frames and skews the folklorist's interpretation. U sing the term as it is used in other disciplines, one might be forced to overlook statements of indifference or ambivalence about priests, no matter how telling they might be, and focus instead on riots and public, rather than private, expressions. 


\section{References}

A ndrews, Ian A lexander. 1987. "M ilitary A id to the Civil Power: The Cape Breton Coal Strike of 1909-1910." MA thesis, Department of History, U niversity of $\mathrm{N}$ ew Brunswick.

Balawyder, M arguerite M artha. 1973. "T he Influence of Interest G roups on the Settlement of the Trawlerman's Strike in Petit de G rat in 1970." MA thesis, Faculty of Education, St. Francis Xavier U niversity.

Cohn, Rob. 2000. "Pictures by Ron Cohn." Clan Sinclair. http:// sinclair.quarterman.org/rob/index.html. A ccessed 13 June 2007.

Creighton, Helen. 1957. Bluenose G hosts. Toronto: The Ryerson Press. Donovan, Stewart. 2007. The Forgotten W orld of R.J. M acSween: A Life.

Sydney, N ova Scotia: Cape Breton U niversity Press.

Feintuch, Burt. 2004. "The Conditions for Cape Breton Fiddle M usic:

The Social and Economic Setting of a Regional Soundscape." Ethnomusicology 48(1): 73-104.

Gibson, John G. 1998. Traditional G aelic Bagpiping, 1745-1945.

M ontreal: M cG ill-Q ueen's U niversity Press.

Graham, G lenn. 2006. The Cape Breton Fiddle: M aking and $M$ aintaining

Tradition. Sydney: Cape Breton University Press.

Grant, Joe, lyricist. 2006. "Burn Ye Fiddles Burn." Gopher Baroque.

Shipwrecked W hisky. CD. Independent release.

"H ighland Legacy: The M usic Traditions of Cape Breton." 2006. DVD. Sea-C ape M usic Ltd.

"History of St. Mary's Parish." [n.d.] 61 paragraphs. http:// www.mabou.net/stmary/H istory.htm. A ccessed 13 June 2007.

Jackson, Kenneth H. 1952. "The Folktale in Gaelic Scotland."

Proceedings of the Scottish A nthropological and Folklore Society 6: 123140.

Johnston, Rev. A ngus A nthony. 1971. A H istory of the C atholic C hurch

in Eastern N ova Scotia: Volume II - 1827-1880. A ntigonish: St.

Francis Xavier U niversity Press.

Kalèik, Susan, 1975. “... Like A nn's G ynecologist or the Time I W as A Imost

Raped: Personal Narratives in Women's Rap Groups." Journal of A merican Folklore 88(347): 3-11.

Kennedy, Willie. 2002. "C ape Breton Fiddler." Liner notes to W illie Kennedy, Cape Breton Violin. Rounder Records CD 7043. A vailable at http://www.mustrad.org.uk/articles/kennedy.htm. 34 paragraphs. A ccessed 13 June 2007. 
M acG illivray, A llister. 1981. The Cape Breton Fiddler. Sydney: C CB Press.

M acl saac, A shley. 1995. "Devil in the Kitchen." In H i, H ow A re You Today? CD. Linus Entertainment.

M acKinnon, Ian Francis. 1989. "Fiddling to Fortune: The Role of

Commercial Recordings $\mathrm{M}$ ade by $\mathrm{C}$ ape Breton Fiddlers in the Fiddle M usic Tradition of Cape Breton Island." M A thesis, Department of Folklore, Memorial U niversity of N ewfoundland.

$M$ acLean, Tristan. [n.d.] "Staying A live: Report on Cape Breton

Concerts and Festivals." U npublished paper prepared for Celtic Studies 299, University College of C ape Breton. Beaton Institute A rchives.

Mahalik, David. 1996. "M usic as a Living Tradition." In Carol Corbin and Judith $A$. Rolls eds., $T$ he $C$ entre of the World at the $E$ dge of the C ontinent: Cultural Studies of C ape Breton Island: 101-104. Sydney: U niversity of Cape Breton Press.

Mellor, John. 1984. The Company Store: James Bryson M CLachlan and the Cape Breton Coal M iners 1900-1925. Halifax: Goodread Biographies.

N arváez, Peter. 2003. "Tricks and Fun: Subversive Pleasures at N ewfoundland Wakes." In Peter N arváez ed., O f C orpse: D eath and $\mathrm{H}$ umor in Folklore and Popular C ulture: 113-139. Logan, U tah: U tah State U niversity Press.

N ilsen, Kenneth E. 1996-1997. "The Role of the Priest in the Gaelic Folklore of N ova Scotia." Béaloideas 64-65: 171-194.

Perlman, Ken. 2002. T he Fiddle M usic of Prince $E$ dward Island: C eltic and A cadian Tunes in Living Traditions. Rev. ed. Pacific, M O: M el Bay Publications.

Rankin, Rev. D. [Duncan] J. 1945. Reverend Kenneth J. M acD onald. [n.p.] Beaton Insitute A rchives Pamphlet 195. O riginally published in 1944-45, Canadian Catholic H istorical A ssociation Report 12: 109-116.

Taylor, Lawrence J. 1990. "Stories of Power, Powerful Stories: The Drunken Priest in Donegal." In Ellen Badone ed., Religious 0 rthodoxy \& Popular Faith in European Society: 164-84. Princeton: Princeton U niversity Press.

The Vanishing C ape Breton Fiddler. 1972. Documentary. CBC Television. Thompson, M arie. 2003. "T he Fall and $\mathrm{R}$ ise of the $\mathrm{C}$ ape Breton Fiddler: 1955-1982." M A thesis. A tlantic Canadian Studies, Saint Mary's U niversity. 
- - - 2006. "The Myth of the Vanishing Cape Breton Fiddler: The Role of a CBC Film in the Cape Breton Fiddle Revival." A cadiensis 35(2): 5-26.

Thompson, Stith. 1946. The Folktale. N ew York: Holt, Rinehart and Winston.

- - - 1955-1958. M otif-Index of Folk-Literature (six volumes). Bloomington: Indiana U niversity Press.

Tye, Diane. 1989. "Local Character A necdotes: A N ova Scotia Case Study." Western Folklore 48(3): 181-199. 